\title{
AKTIVITAS PROTEASE PADA GETAH BAGIAN BATANG DARI TIGA JENIS SPESIES TANAMAN KAMBOJA (Plumeria L)
}

\author{
K. Ratnayani*, M. Nazib, J. Sibarani, dan A.A.I.A M. Laksmiwati \\ Progam Studi Kimia Fakultas Matematika dan Ilmu Pengetahuan Alam Universitas Udayana \\ *Email: ketut_ratnayani@unud.ac.id
}

\begin{abstract}
ABSTRAK
Penelitian ini bertujuan untuk melakukan uji aktivitas protease pada getah bagian batang dari tiga spesies tanaman kamboja yaitu Plumeria rubra L, Plumeria obtusa L dan Plumeria pudica Jacq yang banyak dibudidayakan di wilayah Bali. Pengujian aktivitas protease dilakukan secara spektrofotometri (metode Kurnitz termodifikasi) menggunakan kasein sebagai substrat. Hasil penentuan aktivitas protease pada tiga spesies tanaman kamboja menunjukkan bahwa spesies Plumeria rubra L. memiliki aktivitas protease rata-rata relatif lebih tinggi yaitu $0,0398 \pm 0,00034 \mathrm{U} / \mathrm{mL}$, disusul oleh spesies Plumeria pudica Jacq. yaitu 0,0371 $\pm 0,00019$ U/mL, dan Plumeria obtusa L. yaitu 0,0365 $\pm 0,00032 \mathrm{U} / \mathrm{mL}$. Spesies Plumeria rubra L. merupakan jenis tanaman kamboja yang paling umum, memiliki paling banyak varietas dan paling banyak dibudidayakan di wilayah Bali dibandingkan spesies lainnya. Dari hasil penelitian ini dapat diketahui bahwa jenis ini berpotensi sebagai sumber protease alternatif.
\end{abstract}

Kata kunci: aktivitas protease, getah kamboja, tiga spesies

\begin{abstract}
This research aimed to determine the protease activity of the stem latex of three species of frangipani plant, namely Plumeria rubra L, Plumeria obtusa L and Plumeria pudica Jacq which are mostly cultivated in Bali region. The assay of protease activity was based on spectrofotometric determination with Kurnitz modified method using casein as the substrate. The result of the protease activity assay of the three species of frangipani plant showed that the species of Plumeria rubra $L$. had the protease activity relatively higher than others which was of $0.0398 \pm 0.0003 \mathrm{U} / \mathrm{mL}$, followed by Plumeria pudica Jacq. species which was of $0.0371 \pm 0.0002 \mathrm{U} / \mathrm{mL}$, and Plumeria obtusa L.which was of $0.0365 \pm 0.0003$. The species of Plumeria rubra L. is the most common frangipani species cultivated in Bali region. The results of this study suggested that this plant is potential as an alternative of protease source.
\end{abstract}

Keywords: protease activity, frangipani latex, three species

\section{PENDAHULUAN}

Tanaman kamboja (Plumeria sp) merupakan salah satu jenis tanaman hias yang saat ini banyak dibudidayakan di wilayah Bali, bahkan telah menjadi tanaman ikon Bali. Keunggulan tanaman kamboja memiliki banyak khasiat sebagai tanaman obat sehingga telah banyak diteliti secara lengkap dari segi fitokimianya tentang berbagai kandungan senyawa aktifnya seperti yang dirangkum oleh Farooque et al, 2012. Namun masih sangat sedkit kajian dari aspek biokimianya (khususnya aktivitas enzimatisnya) yang meneliti tanaman tersebut. Salah satu enzim yang telah berhasil diisolasi dari getah tanaman kamboja adalah enzim protease yang diberi nama plumerin (Chanda et a.l, 2011). Enzim protease berperan dalam proses degradasi protein contohnya pada industri makanan (roti, susu, hidrolisat protein), industri deterjen, dan secara tradisional digunakan sebagai pelunak daging. Tingginya harga jual dan pentingnya enzim protease membuat para ilmuwan terpacu untuk mencari sumber-sumber enzim protease baru yang menghasilkan lebih banyak protease dengan aktivitas tinggi. Tanaman merupakan sumber enzim protease yang terbesar yaitu $43,85 \%$ (Mahajan and Shamkant, 2010).

Saat ini di wilayah Bali, berkembang berbagai jenis spesies kamboja, bunga kamboja dapat berwarna merah, kuning, putih, dan terdapat beberapa persilangan menghasilkan warna orange, merah tua dan merah muda. Para pakar botani mengemukakan 4 jenis kamboja yakni, Plumeria obtusa, Plumeria pudica, Plumeria rubra, dan Plumeria acutifolia. Selain 4 jenis tersebut, dikenal pula Plumeria rubra yang memiliki tiga warna dalam satu kelopak yaitu 
rubra tricolor dan beberapa persilangan yang memiliki warna bunga dan kelopak bervariasi yaitu rubra hybrida. Spesies Plumeria rubra memiliki daun dan kelopak bunga yang meruncing, sedangkan Plumeria obtusa memiliki ujung daun dan kelopak bunga yang membulat. Berkembangnya berbagai spesies kamboja menimbulkan ketertarikan untuk meneliti apakah terdapat perbedaan sifat-sifat yang menonjol dari masing-masing spesies tersebut khususnya dari segi enzimatisnya.

Berdasarkan latar belakang tersebut, maka perlu dilakukan penelitian untuk menentukan aktivitas protease yang terkandung pada getah tanaman dari tiga jenis spesies tanaman kamboja yang banyak dibudidayakan di wilayah Bali khususnya wilayah Kecamatan Abiansemal Kabupaten Badung yaitu Plumeria obtusa L, Plumeria pudica Jacq, dan Plumeria rubra L. Aktivitas protease ditentukan dengan metode Kurnitz yang dimodifikasi yaitu dengan cara mereaksikan ekstrak kasar protease dengan substrat kasein selama 30 menit.

\section{MATERI DAN METODE}

\section{Bahan}

Bahan-bahan dan materi yang digunakan pada penelitian ini adalah sampel getah tiga jenis spesies tanaman kamboja (Plumeria rubra L, Plumeria obtusa L, dan Plumeria pudica Jacq) yang dibudidayakan di wilayah kecamatan Abiansemal, Badung, Bali, tirosin, kasein, $\mathrm{NaOH}$, Buffer fosfat ( $\mathrm{pH} 7$ ), Natrium metabisulfit $\left(\mathrm{Na}_{2} \mathrm{~S}_{2} \mathrm{O}_{5}\right)$, dan Asam Trikloroasetat (TCA).

\section{Peralatan}

Alat Alat-alat yang digunakan dalam penelitian ini adalah peralatan gelas, thermos es, alat sentrifugasi, pipet mikro, alat vortex, lemari pendingin, neraca analitik, inkubator, spektrofotometer UV-Vis Genesys 10S.

\section{CARA KERJA}

\section{Pengumpulan sampel getah kamboja}

Pengambilan sampel getah kamboja dilakukan dengan memotong bagian pucuk batang kamboja dengan menggunakan pisau stainless steel, kemudian getah yang menetes ditampung dalam tabung sentrifugasi. Sebanyak $1 \mathrm{~mL}$ sampel getah selanjutnya ditambahkan ke dalam $1 \mathrm{~mL}$ buffer fosfat $\mathrm{pH} 7$ yang telah mengandung Na-metabisulfit $10 \%$ yang bertujuan agar sampel getah terhindar dari proses oksidasi dan disimpan dalam termos es. Getah kemudian disaring dengan kapas untuk memisahkan getah dengan damar yang bersifat lengket, sehingga bagian damarnya akan menempel di dalam kapas, sedangkan bagian cairannya akan lolos yang merupakan getah bebas damar.

\section{Preparasi ekstrak kasar protease}

Proses ekstraksi dilakukan pada suhu $4^{\circ} \mathrm{C}$ untuk meminimalkan efek denaturasi enzim. Sebanyak $1 \mathrm{~mL}$ sampel getah tanaman bebas damar disentrifugasi pada kecepatan $7000 \mathrm{rpm}$ selama 30 menit pada suhu $4^{\circ} \mathrm{C}$ dan supernatan yang dihasilkan siap digunakan sebagai sampel dalam uji aktivitas protease. Ekstrak protease kasar selanjutnya disimpan dalam lemaris es pada suhu $4^{\circ} \mathrm{C}$.

\section{Uji aktivitas ekstrak kasar protease}

Sebanyak $1 \mathrm{~mL}$ larutan kasein $0,65 \%$ ditambahkan dengan $1 \mathrm{~mL}$ ekstrak protease kasar lalu divortex dan diinkubasi selama 10 menit pada suhu $50^{\circ} \mathrm{C}$, kemudian sebanyak 5 $\mathrm{mL}$ larutan TCA 5\% ditambahkan ke dalam larutan tersebut lalu divortex kembali dan didiamkan selama 5 menit. Campuran disentrifugasi pada kecepatan $6000 \mathrm{rpm}$ selama 10 menit. Supernatan yang didapat diukur absorbansinya pada panjang gelombang $280 \mathrm{~nm}$ terhadap larutan blanko. Untuk penentuan jumlah tirosin, maka dilakukan pembuatan kurva standar tirosin dengan memvariasikan konsentrasi tirosin standar menjadi 2,$20 ; 4,40 ; 6,60 ;$ dan 8,$80 ; \mu \mathrm{M}$. Adapun regresi linier kurva standar tirosin yang diperoleh $y=0,1070 x+0,0224$ dengan koefesien regresi linier (r) sebesar 0,9905.

\section{HASIL DAN PEMBAHASAN}

\section{Hasil determinasi dan karakter tanaman kamboja}

Hasil determinasi yang dilakukan oleh Balai Konservasi Tumbuhan Kebun Raya "Eka Karya" Bali-LIPI menunjukkan bahwa tiga spesies tanaman kamboja yang digunakan dalam penelitian ini berturut-turut termasuk ke dalam jenis spesies Plumeria rubra $L$, Plumeria obtusa L dan Plumeria pudica Jacq. Determinasi tanaman penting dilakukan untuk memastikan ketetapan pemilihan tanaman. 
Pada Tabel 1. diberikan penjelasan tentang karakteristik fisik yang membedakan masingmasing spesies tersebut, sedangkan bentuk fisik tiga spesies tanaman kamboja yang digunakan yaitu Plumeria rubra L, Plumeria obtusa $L$ dan Plumeria pudica Jacq. ditunjukkan pada Gambar 1.

\section{Pengujian aktivitas protease}

Uji aktivitas protease yang dilakukan dalam penelitian ini, ditentukan dengan uji kaseinolitik yang memanfaatkan kasein sebagai substrat pada suhu, $\mathrm{pH}$, dan lama waktu tertentu. Reaksi hidrolisis yang terjadi selanjutnya dihentikan dengan menambahkan larutan TCA (asam trikloroasetat). Sehingga enzim dan sisa substrat protein yang tidak terhidrolisis akan terdenaturasi oleh adanya TCA, yang akan mengendap, sedangkan produk hasil hidrolisis yang berupa asam amino (salah satunya yaitu tirosin) tidak mengendap oleh TCA dan akan terlarut dalam supernatan. Tirosin yang larut dalam supernatan tersebut selanjutnya dipisahkan dari enzim dan sisa substrat dengan cara disentrifugasi dan ditentukan serapannya pada $280 \mathrm{~nm}$.

Jumlah asam amino hasil hidrolisis (yang dalam hal ini diwakili oleh tirosin) digunakan untuk menentukan aktivitas protease getah tanaman. Semakin banyak produk tirosin hasil hidrolisis maka semakin besar aktivitas protease ekstrak protease kasar getah tanaman atau semakin banyak pula molekul protein yang dipecah menjadi monomer penyusunnya. Tirosin yang terbentuk dipisahkan dari protein enzim dan sisa substrat dengan melakukan sentrifugasi, setelah itu supernatan yang dihasilkan dapat ditentukan konsentrasi tirosinnya pada $\lambda$ maks $(280 \mathrm{~nm})$. Banyaknya molekul tirosin $(\mu \mathrm{mol})$ selanjutnya dihitung dengan mengkonversikan konsentrasi tirosin hasil hidrolisis ( $\mu \mathrm{mol})$. Jumlah tirosin hasil hidrolisis dapat dilihat pada Tabel 2.

\section{Aktivitas protease pada getah tiga jenis spesies tanaman kamboja}

Aktivitas protease $(\mathrm{U} / \mathrm{mL})$ dinyatakan dalam unit aktivitas, yaitu satu unit (U) dinyatakan sebagai jumlah protease yang menyebabkan peningkatan satu unit absorbansi per menit reaksi hidrolisis. Perbandingan aktivitas protease dari tiga spesies tanaman kamboja tersebut dicantumkan pada Tabel 3. Berdasarkan Tabel 3, menunjukkan bahwa spesies Plumeria rubra L., memiliki aktivitas protease rata-rata relatif lebih tinggi daripada dua spesies lainnya yaitu $0,0398 \pm 0,0003$ $\mathrm{U} / \mathrm{mL}$, disusul oleh spesies Plumeria pudica Jacq., yaitu sebesar $0,0371 \pm 0,0002 \mathrm{U} / \mathrm{mL}$, dan Plumeria obtusa L., yaitu $0,0365 \pm 0,0003$ $\mathrm{U} / \mathrm{mL}$. Nilai aktivitas protese pada getah ketiga jenis spesies tananman kamboja ini masih lebih tinggi daripada aktivitas protease yang ditemukan pada getah umbi talas $(0,0123$ $\mathrm{U} / \mathrm{mL})$ dan getah buah labu siam $(0,0264$ $\mathrm{U} / \mathrm{mL}$ ) (Ratnayani et al., 2015).

Selain itu, nilai aktivitas protease getah kamboja mendekati nilai aktivitas protease relatif getah tanaman sodom apple (Calotropis procera (Ait.) R.Br.) yang mencapai 0,052 $\mathrm{U} / \mathrm{mL}$. Tanaman sodom apple merupakan tanaman yang sering digunakan dalam proses pengendapan susu (milk clotting) atau pembuatan keju (Oseni and Ekperigin, 2013). Jenis Plumeria rubra L. merupakan spesies kamboja yang paling banyak dibudidayakan di wilayah Bali, paling variatif warna bunganya dan paling mudah dibudidayakan. Melimpahnya budidaya tanaman kamboja khususnya spesies Plumeria rubra L. di wilayah Bali, menunjukkan bahwa tanaman ini berpotensi sebagai sumber protease alternatif.

Berdasarkan penelitian yang dilakukan oleh Oseni and Ekperigin(2013) ditemukan bahwa bagian getah tumbuhan Calotropis procera(Sodom apple) memiliki aktivitas protease yang jauh lebih tinggi dibandingkan bagian tanaman lain (akar, batang muda, daun, buah). Kelebihan lain dari penggunaan protease dari getah kamboja yaitu proses isolasi enzim dari getah relatif lebih sederhana dan efisien, mengingat enzim protease getah merupakan enzim ekstraselular sehingga proses isolasinya dapat dilakukan tanpa tahap pemecahan/lisis sel tumbuhan. Selain itu juga dapat diperoleh isolat enzim yang relatif lebih murni karena dapat dihindari adanya pencampuran enzim lain yang sebagian besar adalah intraselular sehingga tahap isolasi menjadi lebih singkat. Pemanfaatan protease getah diharapkan dapat meningkatkan nilai komersial getah yang selama ini dianggap sebagai limbah dari produk tanaman tersebut. 
Tabel 1. Karakteristik Fisik Ketiga Spesies Kamboja.

\begin{tabular}{ll}
\multicolumn{1}{c}{ Spesies Kamboja } & \multicolumn{1}{c}{ Karakteristik } \\
\hline Plumeria obtusa L. & $\begin{array}{l}\text { Ujung daun dan kelopak bunga membulat, permukaan daun licin dan } \\
\text { mengkilat. Warna hijau daun lebih tua. Warna bunga putih. }\end{array}$ \\
\hline $\begin{array}{l}\text { Plumeria pudica } \\
\text { Jacq. }\end{array}$ & $\begin{array}{l}\text { Bentuk daun bertekuk, diameter batang lebih kecil, mahkota bunga } \\
\text { lebih tipis, kumpulan bunga membentuk bouquet pada ujung atas } \\
\text { batang. Warna bunga putih. Jenis kamboja ini sering disebut kamboja } \\
\text { pagoda. }\end{array}$ \\
\hline Plumeria rubra L. & $\begin{array}{l}\text { Ujung daun dan kelopak bunga runcing, memiliki paling banyak } \\
\text { varietas. Jumlah bunga lebih banyak, dan merupakan spesies yang } \\
\text { paling banyak dibudidayakan di wilayah Bali. Jenis spesies ini paling } \\
\text { banyak memiliki varietas sehingga menghasilkan berbagai warna } \\
\text { bunga yang menarik. Salah satu varietasnya yang terkenal adalah } \\
\text { Plumeria rubra var Tricolor di wilayah Bali disebut jepun sudamala } \\
\text { dengan aroma harum dan berwarna. }\end{array}$ \\
\hline
\end{tabular}

Tabel 2. Jumlah Tirosin Hasil Hidrolisis

\begin{tabular}{|c|c|c|c|c|c|c|}
\hline \multirow[t]{2}{*}{ Spesies Kamboja } & \multirow[t]{2}{*}{ Ulangan } & \multicolumn{4}{|c|}{ Absorbansi } & \multirow{2}{*}{$\begin{array}{c}\text { Jumlah Tirosin } \\
\text { Hasil Hidrolisis } \\
(\mu \mathrm{mol})\end{array}$} \\
\hline & & A1 & $\mathbf{A 2}$ & A3 & Rata-rata & \\
\hline \multirow[t]{4}{*}{ Plumeria rubra L } & 1 & 0,874 & 0,876 & 0,882 & 0,877 & 0,0564 \\
\hline & 2 & 0,874 & 0,891 & 0,888 & 0,884 & 0,0570 \\
\hline & 3 & 0,886 & 0,869 & 0,892 & 0,882 & 0,0569 \\
\hline & & & & & Rata-rata & $\underline{0,0568}$ \\
\hline \multirow[t]{4}{*}{ Plumeria obtusa L } & 1 & 0,810 & 0,810 & 0,810 & 0,810 & 0,0519 \\
\hline & 2 & 0,811 & 0,818 & 0,813 & 0,814 & 0,0522 \\
\hline & 3 & 0,824 & 0,820 & 0,827 & 0,823 & 0,0528 \\
\hline & & & & & Rata-rata & $\underline{\mathbf{0 , 0 5 2 3}}$ \\
\hline \multirow[t]{4}{*}{ Plumeria pudica Jacq } & 1 & 0,800 & 0,819 & 0,821 & 0,813 & 0,0530 \\
\hline & 2 & 0,821 & 0,812 & 0,823 & 0,819 & 0,0534 \\
\hline & 3 & 0,823 & 0,834 & 0,829 & 0,829 & 0,0540 \\
\hline & & & & & Rata-rata & $\underline{\mathbf{0 , 0 5 3 5}}$ \\
\hline
\end{tabular}

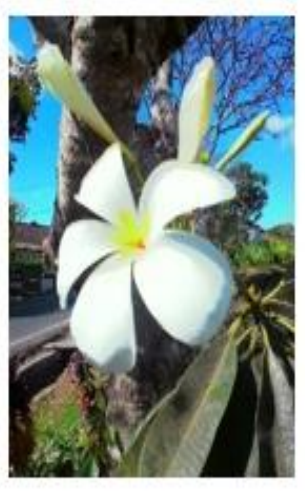

a

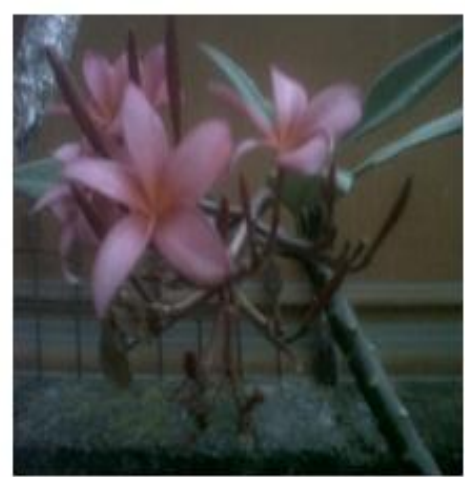

b

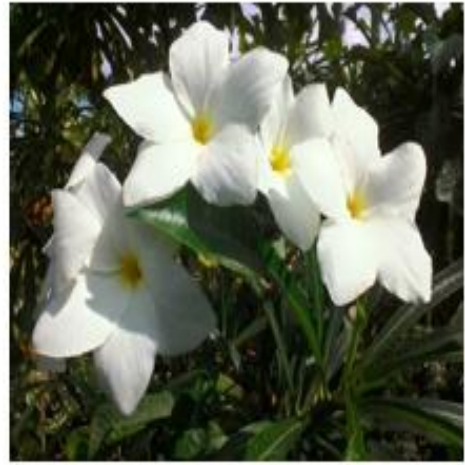

c

Gambar 1. Tiga spesies tanaman kamboja yang menjadi obyek penelitian. (a). Plumeria obtusa L. (b). Plumeria rubra L.(c). Plumeria pudica Jacq. 
Aktivitas Protease pada Getah Bagian Batang dari Tiga Jenis Spesies Tanaman Kamboja (Plumeria L)

(K. Ratnayani, M. Nazib, J. Sibarani, dan A.A.I.A M. Laksmiwati)

Tabel 3. Aktivitas protease getah batang tiga jenis spesies tanaman kamboja

\begin{tabular}{cc}
\hline Spesies Kamboja & $\begin{array}{c}\text { Rata - rata } \\
\text { Aktivitas Protease } \\
\text { (U/mL) }\end{array}$ \\
\hline Plumeria rubra & $0,0398 \pm 0,00034$ \\
\hline Plumeria obtusa & $0,0365 \pm 0,00032$ \\
\hline Plumeria pudica & $0,0371 \pm 0,00019$ \\
\hline
\end{tabular}

\section{SIMPULAN DAN SARAN}

\section{Simpulan}

Aktivitas protease Plumeria rubra L, Plumeria pudica Jacq dan Plumeria obtusa L berturut-turut adalah $0,0398 \pm 0,00034 \mathrm{U} / \mathrm{mL}$, $0,0371 \pm 0,00019 \mathrm{U} / \mathrm{mL}$, dan $0,0365 \pm$ $0,00032 \mathrm{U} / \mathrm{mL}$. Spesies Plumeria rubra $L$ memiliki aktivitas protease relative lebih tinggi daripada dua spesies lainnya, Melimpahnya budidaya tanaman kamboja khususnya spesies Plumeria rubra L. di wilayah Bali, menunjukkan bahwa tanaman ini berpotensi sebagai sumber protease alternatif.

\section{UCAPAN TERIMAKASIH}

Penulis mengucapkan terima kasih kepada LPPM UNUD atas bantuan dana yang diberikan melalui Hibah Penelitian Dosen Muda dana DIPA-PNPB dengan Kontrak Nomor: $\quad 1293 / \mathrm{UN} 14.1 .28 .1 / \mathrm{PP} / 2015$, serta semua pihak yang memberikan dukungan dan saran hingga penelitian ini terselesaikan dengan baik.

\section{DAFTAR PUSTAKA}

Chanda, I., S. K. Basu, S. K. Dutta, and S. R. C. Das, 2011, A Protease Isolated from the Latex of Plumeria Rubra Linn (Apocynaceae) 1: Purification and Characterization, Tropical Journal of Pharmaceutical Research, 10 (6): 705-711

Farooque, A.M.D., A. Mazumder, S. Shambhawee, and R. Mazumder, 2012, Review On Plumeria Acuminata, International Journal of Research In Pharmacy and Chemistry, 2 (2): 467- 469.

Mahajan, R.T., and B.B. Shamnkant, 2010, Biological aspects of proteolytic enzymes, Journal Pharmacy Research, 3 (9): 2048-2068.

Oseni, O. A., and M. M, Ekperigin, 2013, Partial Characterization of Proteolytic and Milk Clotting Enzymes in Sodom Apple Calotropis procera (Ait.) R.Br. (Asclepiadaceae) Plant, American Journal of Biochemistry and Molecular Biology, 3: 256-263.

Ratnayani, K., S. Juwarni, A. A. I. A. M. Laksmiwati, 2015, Uji Aktvitas Protease Getah Labu Siam dan Talas Serta Perbandingannya Terhadap Getah Pepaya, Jurnal Kimia, 9 (2): 147-152. 